\title{
Large Shareholding and Firm Value in the Alternative Investment Market (AIM)
}

\author{
Mona Mortazian, \\ Brunel university London, Kingstone Lane, Uxbridge, UB8 3PH, UK, \\ mona.mortazian2@brunel.ac.uk \\ Seyedeh Asieh H.Tabaghdehi ${ }^{1}$ \\ Regents University London, Inner Circle, Regents Park, London, NW1 4NS, UK, \\ hosseinits@regents.ac.uk \\ Bryan Mase \\ Brunel university London, Kingstone Lane, Uxbridge, UB8 3PH, UK, \\ bryan.mase@brunel.ac.uk
}

\begin{abstract}
This paper investigates the impact of non-managerial and managerial blockholders on the value of the firms listed in the Alternative Investment Market (AIM). This study mainly investigates whether the effect of blockholders on firm value is due to the AIM high ownership concentration and low investor protection. The primary empirical finding, using GMM, justifies that non-managerial and managerial blockholders in the AIM affect the firm value in different ways. Non-managerial blockholders in the AIM improve the firm value by monitoring managers when their block sizes are up to 32 per cent. However, when their block sizes exceed 32 per cent, the blockholders expropriate other shareholders.
\end{abstract}

Keywords: Corporate governance, Alternative Investment Market (AIM), Managerial blockholders, Firm value, Tobin's Q, Generalized Method of Moments (GMM)

JEL Classification: G23, G32

\section{Introduction}

Corporate governance is one of the most disputable topics in finance that is vastly associated with , market value, profit, and the efficiency and effectiveness of the economic system. Furthermore its’ importance has been emphasized widely in early literatures [Yermack (1996), Gompers et al. (2001), Klapper and Love (2004), Florackis et al (2009), and Vukčević (2012)].

\footnotetext{
${ }^{1}$ Corresponding author
} 
The Ownership structure is also recognized as one of the main corporate governance mechanisms where the correlation between ownership structure and firm value initiate from the separation of ownership and management (Berle and Means, 1932, Velury and Jenkins (2006)). This is known as agency theory, which explains managers and owners have different interests (Jensen and Meckling, 1976; Fama and Jensen, 1983). However to avoid being expropriated by managers, shareholders tend to control them, whereas monitoring companies' managers and gaining information imposes costs on shareholders and results in a free rider problem ${ }^{2}$ (Grossman and Hart, 1980; Edmans, 2014). On the other hand, group of shareholders might be controlling shareholders (Bonaventura et al. 2017); this group normally includes large shareholders, known as blockholders, ${ }^{3}$ that can play an important role in governance because their large stakes motivate them to accept the costs of monitoring managers (Edmans, 2014).

The early literatures show that the impact of blockholders on corporate governance depends on the level of ownership concentration (Khan et al., 2005, Thomsen et al., 2006; Basu et al., 2016) and regulations in each market (Lins, 2003). However, from there the relationships between non-managerial and managerial blockholders and the firm value is not conclusive.

Considering the Alternative Investment Market (AIM) of London Stock Exchange market, by growing the AIM, its market regulatory framework has evolved continuously to protect investors. Nonetheless, it still needs to balance its regulations to meet the demands of small and growing companies as well as investors. This has been indicated in early literature that the ownership concentration in the UK is low and the investor protection is high, and as result the impact of blockholders on the firm value is insignificant.

However, the opposite relationship is expected between blockholders and firm value in the AIM -firstly because the main market emphasises the independent operations of the companies $^{4}$ and does not allow companies with blockholders owning more than 30 per cent of

\footnotetext{
2 Outside investors face a risk of not receiving a return on their investment because the controlling shareholders or managers expropriate them. Shareholders who wish to monitor managers have to accept all the costs but earn just a fraction of profit. Because they are not the only shareholders and profit will be divided among all the company's shareholders, this problem is defined by Grossman and Hart (1980) as the free rider problem.

${ }^{3}$ Blockholders are defined as shareholders who own more than five per cent of total shares.

${ }^{4}$ The board, managerial and operational independence code includes a number of requirements to ensure the independency of the company's board, management and operations that might not be possible under regimes with fewer requirements and especially in the context of closely held companies. These include the regulations that at least 50 per cent of the board should be made up of independent non-executive directors, that the roles of chairman and chief executive should be separated, and that firms have to follow certain minimum requirements for the establishment, composition and responsibilities of board committees.
} 
total shares to list in the market, while there is no limitation on the blockholding for companies listing in the AIM (Witty et al., 2012), and high ownership concentration is thus expected in the AIM; and secondly, all the companies listed in the main market should consider the requirements of the UK Corporate Governance Code and provide the required disclosure in their annual report as to their agreement with the Code; conversely, companies in the AIM do not have to prepare requirements that are equivalent to the Code (Murphy et al., 2012). Hence investor protection is lower in the AIM than the main market. Therefore, it can be concluded that the value of the firms listed in the AIM might be affected significantly by blockholders because of the possibility of high ownership concentration and lower investor protection.

In this study we investigate the impact of blockholders on the value of the firms listed in the AIM by examining the impact of non-managerial and managerial blockholders on the value of the firms listed in the AIM. More specifically here, the main research question is to investigate whether the managerial and non-managerial blockholders impacting the firm value significantly in the AIM due to the AIM has high ownership concentration and low investor protection.

Here, the sample used includes 443 companies listed in the AIM on 31 $31^{\text {st }}$ December 2013 and having blockholder ownership of at least five per cent of total shares and a minimum of six years data available. Also, the sample is divided into two groups of 125 managerial blockholders and 318 non-managerial blockholders. Moreover, as ownership is an endogenous variable in analysing the relationship between ownership concentration and the firm value (Miguel et al., 2006), and this endogeneity can be in the form of dynamic or reverse causality (Henry, 2010), the impact of blockholders on the firm value is examined using the generalised method of moment (GMM) to control the dynamic aspect and Granger causality to control the reverse causality aspect of endogeneity.

The primary empirical finding justifies that non-managerial and managerial blockholders in the AIM affect the firm value in different ways. Non-managerial blockholders in the AIM improve the firm value by monitoring managers when their block sizes are up to 32 per cent. However, when their block sizes exceed 32 per cent, the blockholders expropriate other shareholders.

Hence this study finds evidence for both monitoring and expropriation hypotheses by finding a quadratic relationship between non-managerial blockholders and firm value. Furthermore, examining the impact of managerial blockholders and the firm value illustrates that managerial 
blockholders have a cubic relationship with firm value. This cubic relationship explains the relationship between managerial blockholders and the firm value as follow:

- managers who own between 5 and 31 per cent of total shares improve the firm value because their interests converge with the interests of other shareholders;

- managers who own between 31 and 54 per cent of total shares enrich themselves at the expense of other shareholders and thus decrease the firm value;

- finally, the group of managers having more than 54 per cent of total shares increases the firm value again, because their interests are converged with those of other shareholders.

In this study section 2 debates the relevant literatures. Section 3 discusses about the data and methodology. Section 4 describes the empirical findings and finally section 5 concludes the article.

\section{Literature Review}

An agency problem arises from the separation of ownership and control; thus, because of the separated goals of managers and shareholders, management might run the company for their own benefit instead of the shareholders' benefit (Jensen and Meckling, 1976; Fama and Jensen, 1983; Dyl, 1988). Monitoring managers is costly; therefore, shareholders with small shares rely on just the markets' regulations to protect themselves from being expropriated by managers ( $\mathrm{La}$ Porta et al., 2000). However, if the blockholders are also the managers of the company, they can affect the firm value more easily because they have both cash flow and control rights (Lins, 2003). More generally, Ursel and Zhong (2017) show that presence of blockholders, insiders or outsiders decrease the board power.

\section{Non-managerial and Managerial Blockholders and Firm Value}

Hirschman (1982) mentions that blockholders can affect governance by two mechanisms: direct intervention (voice) and exit. According to Edmans (2014), voice includes any activity that a blockholder can carry out that increases a firm's value, while paying costs. Edmans (2014) mentions that generally blockholders who are able to impact the firm's decisions by voice are blockholders with large blocks which enable them to minimize and postpone the disclosure of information in order to increase the chance of fulfilling their plans. Thus, other shareholders might not be able to intervene, or have to make their decisions based on inadequate information. Poor disclosure exacerbates the information asymmetry problem, and 
the large blockholder might trade based on insider information and take advantage of private information.

Edmans et al. (2013) explain that certain blockholders' competitive advantage might be based on selecting stocks, instead of beginning a proxy fight or delivering strategic advices, and advising a manager of a new strategy might be beyond their main strength. In addition, as mentioned by different literatures such as Winton (1993), Noe (2002), and Edmans and Manso (2011), one of the main drivers of governance by voice is block size; therefore, it is difficult for blockholders with small block sizes to control governance by voice. Admati and Pfleiderer (2009), Edmans (2009), and Edmans and Manso (2011) note that blockholders are informed traders that control management by exit. In their models, blockholders' exit exerts downward pressure on the stock price that affects management by its equity interest in the firm. Hence management will try to choose strategies, which persuade blockholders to stay with the company.

However, when managers do not follow the blockholders' recommendations and care about their private benefit, then blockholders will use the option of exit; therefore exit enhances the power of voice. Furthermore, studies such as those by Bharath et al. (2013) and Edmans et al. (2013) conclude that there is one more mechanism that blockholders can use in order to affect governance: this mechanism is threat of exit and voice. Edmans et al. (2013) argue that the absence of voice and exit does not indicate the absence of blockholders' impact on governance; on the contrary, the threat of voice and exit might be enough to encourage the managers to maximize firms 'value.

Various studies support monitoring hypothesis by evaluating the relationship between blockholders and firm value in different markets. They mention that ownership concentration has a positive impact on the firm value by affecting the firm's productivity. (Hill and Snell, 1989).

Different literatures categourized the impact of blockholders on the firm value in different ways for instance, Basu et al. (2016) explain three ways that existing blockholders can impact the firm value. First, expropriation; second, monitoring and third threat of exit. They also mentioned that this impact would be more significant when blockholders' stake is larger. On the other hand, Bennedsen and Nielsen (2010), categorize the impact of blockholders on the firm value based on outcome of the effect, which can be both positive and negative. Bennedsen and Nielsen (2010) explain that positive effect, which they called as incentive effect, makes the 
monitoring effect more efficient; and, on the opposite side, the negative effect called as entrenchment effect, create the opportunity for blockholders to expropriate minority owners.

Berle and Means (1993), Han and Suk (1998), Lins (2003), Cheung et al. (2005) and Jiang et al. (2011) suggest that the impact of managerial blockholders on the firm value might be different from the impact of outside blockholders because a large number of the firms have managers whose control rights exceed their cash flow right. ${ }^{5}$ Moreover, as mentioned by To et al. (2017) insiders might have superior information about the firm, Thus as Basu et al. (2016) believe in studying about the impact of blockholders' power on the firm value, it is important to distinguish whether the power is concentrated in the insiders' hands or outsiders' hands. Furthermore, Arifin (2003) notify that in studying managerial blockholders, the role of family ownership ${ }^{6}$ is highlighted as family ownership is very widespread in most developed and developing countries.

Fama and Jensen (1983), McConaughny et al. (2001), Yammeesri and Lodh (2006), Suehiro (2001), and Anderson and Reeb (2003) all believe that as the firms with family ownership are owned and controlled by the same people, the cost of monitoring in these companies decreases and the agency problem is alleviated, all of which results in higher firm value. On the other hand, Maury and Pajuste (2005) show that families having managerial or board representation have more intention to private benefit extraction if they are not monitored by other blockholders.

In early literature Jensen and Meckling (1976) introduce the alignment hypothesis where they refers to the managers' natural tendency to allocate the firm's resources according to their own best interests, which can be in conflict with the interests of outside shareholders and firm value. By increasing insider ownership, the conflicting interests converge; therefore the agency problem between managers and shareholders can be diminished. The convergence of interest hypothesis suggests that by increasing the managerial ownership, firm value ultimately increases. Harris and Raviv (1988) and Stulz (1988) suggest the entrenchment hypothesis, which it shows that excessive managerial ownership has a negative correlation with firm value.

As the London Stock Exchange considers that a comprehensive requirement to 'comply or explain' by reference to a particular code would not be suitable for the smaller, growing

\footnotetext{
${ }^{5}$ Bergström, and Rydqvist (1990), Zingales (1994) and Nenova (2003) mention that, in order to achieve high control rights, managers issue and buy shares with superior voting rights.

${ }^{6}$ Arifin (2003) defines family ownership as managerial blockholders who are part of founding families.
} 
companies that make up the AIM's constituent members, the AIM rules for these companies do not require adherence to a particular set of corporate governance rules (Murphy and Cronin, 2012). Consequently, as the result of weak external corporate governance, AIM blockholders are expected to protect themselves by monitoring managers when their block sizes are small or medium.

Moreover, as mentioned previously, corporate governance of the AIM does not emphasise the independent operations of the companies; therefore blockholders with large stakes can impact a company's operations in order to satisfy their own interests and expropriate small shareholders; in this case, large non-managerial blockholders can decrease the firm value. Therefore the first hypothesis predicts a curvilinear association between ownership concentration and firm value and thus considers both monitoring and expropriation effects. This is plotted in Figure 1.

\section{Hypothesis I: Firm value first rises and, after a breakpoint, declines as block size increases.}

Figure 1. Quadratic relationship between non-managerial blockholders and firm value

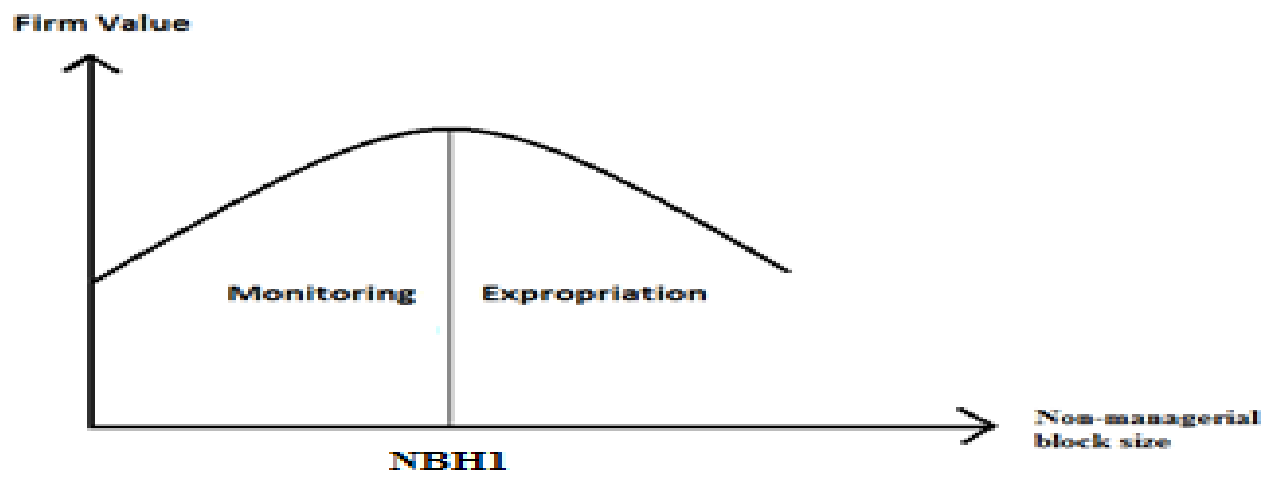

Note: The monitoring and expropriation hypotheses used to explain the relationship between nonmanagerial blockholders and firm value in the AIM. NBH shows non-managerial blockholders.

Here this quadratic equation based on hypothesis I can be express as follow:

$$
\mathrm{FV}_{\mathrm{it}}=\beta_{0}+\beta_{1} \mathrm{NBH}_{\mathrm{it}}+\beta_{2} N B H_{i t}^{2}+\beta_{\mathrm{it}} \mathrm{FV}_{\mathrm{t}-1}+\beta_{\mathrm{it}} \mathrm{C}_{\mathrm{it}}+\varepsilon_{\mathrm{it}}
$$

Where FV is the company market value market, $\mathrm{NBH}$ and $\mathrm{NBH}^{2}$ denote non-managerial block size and its square, $\mathrm{FV}_{\mathrm{t}-1}$ shows lag one of firm value, and $\mathrm{C}$ refers to explanatory and control variables. Here the first control variable is firm size, which controls for the possibility that firm value and ownership are related by the size of the company and measured by log of assets. Leverage is the next control variable, which considers structural differences that companies use in terms of their long- and short-term financing tools in different countries and is measured by 
the ratio of the total long-term and short-term debt to total assets at end of the preceding year. The next control variable is intangible fixed assets as a proxy for future growth opportunities and is calculated as the logarithm of intangible assets at the end of the preceding year. Finally, $\varepsilon_{i t}$ refers to the error term. The first subscript of the variables (i) refers to firms, and the second (t) to business year. From the Figure 1, the firm value first increases because of the monitoring effect and then decreases under the effect of expropriation.

However, Short and Keasey (1999) find some differences between corporate governance mechanisms in the US and the UK, which explain that the entrenchment effect can appear at higher levels of managerial blockholding in the UK. Hence, as the AIM has weaker external corporate governance mechanisms than LSE main market, so the level at which the AIM managerial blockholders enrich might be higher than other managerial blockholders in the main market of the UK. Thus the cubic relationship can be defined to explain the relationship between managerial blockholders and the firm value in the AIM.

This implies firm value first decreases because of enrichment and, at a higher level of managerial ownership, the interests of managers and other shareholders converge and increase the firm value.

\section{Hypothesis II: Firm value first increases, then decreases, and finally continues to increase as managerial block sizes rises}

Figure 2. Cubic relationship between managerial blockholders and firm value

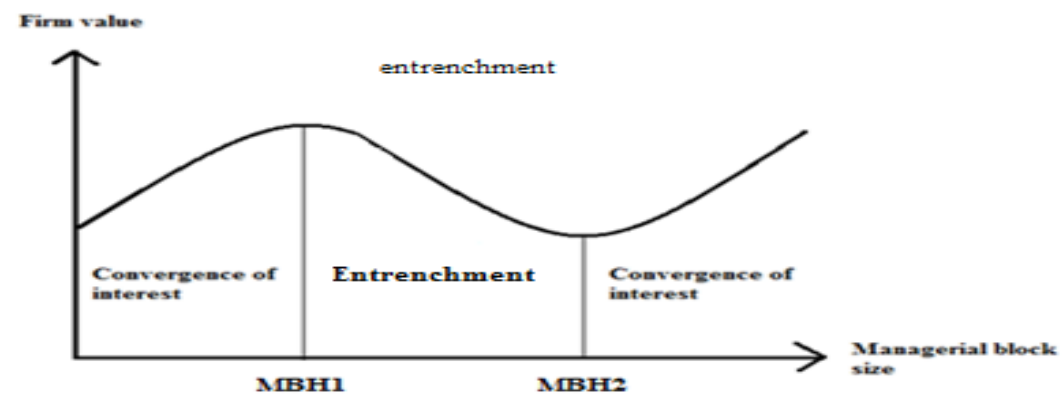

Note: The Convergence of interest and enrichment hypotheses used to explain the relationship between Here this cubic relationship between shareholders' block size and firm value given by equation below.

$$
\mathrm{FV}_{\mathrm{it}}=\omega_{0}+\omega_{1} \mathrm{MBH}_{\mathrm{it}}+\omega_{2} M B H_{i t}^{2}+\omega_{3} M B H_{i t}^{3}+\omega_{\mathrm{it}} \mathrm{FV}_{\mathrm{t}-1}+\omega_{\mathrm{it}} \mathrm{C}_{\mathrm{it}}
$$

Where $\mathrm{MBH}_{\mathrm{it}}$, and refer to managerial block size of firm i in year $\mathrm{t}$, and its square and cube respectively. In next section we review the validity of both hypothesis using range of methods. 


\section{Data and Methodology}

\section{Generalized Method of Moments (GMM)}

To estimate the dynamic model here we justified the relationships between nonmanagerial/managerial blockholders and the firm value using the Generalized Method of Moment (GMM). The early literature by Morck et al. (1988), and McConnell and Servaes (1990), ignored the ownership structure as an endogenous variable in analysing the relationship between ownership concentration and the firm value. This study has the advantage of using panel data which that enable the study to control for unobservable heterogeneity by an individual effect. Furthermore using GMM estimator is an efficient methods taking the endogeneity issue into account as well as both unobserved heterogeneity and endogeneity issues by implementing instruments.

Using equation 3 and 4 given below, we applied the GMM on panel dataset to examine the shape of the relationship, quadratic relationship between non-managerial blockholders and firm value, and cubic relationship between managerial blockholders and firm value.

$$
\begin{aligned}
& \mathrm{FV}_{\mathrm{it}}=\beta_{0}+\beta_{1} \mathrm{NBH}_{\mathrm{it}}+\beta_{2} N B H_{i t}^{2}+\beta_{\mathrm{it}} \mathrm{FV}_{\mathrm{t}-1}+\beta_{\mathrm{it}} \mathrm{C}_{\mathrm{it}}+\mathrm{d}_{\mathrm{t}}+\eta_{\mathrm{i}}+v_{\mathrm{it}} \\
& \mathrm{FV}_{\mathrm{it}}=\omega_{0}+\omega_{1} \mathrm{MBH}_{\mathrm{it}}+\omega_{2} M B H_{i t}^{2}+\omega_{3} M B H_{i t}^{3}+\omega_{\mathrm{it}} \mathrm{FV}_{\mathrm{t}-1}+\omega_{\mathrm{it}} \mathrm{C}_{\mathrm{it}}+\mathrm{d}_{\mathrm{t}}+\eta_{\mathrm{i}}+v_{\mathrm{it}}
\end{aligned}
$$

Where $d_{t}$ that measures the temporal effect with the corresponding dummy variables is considered, hence the effect of macroeconomic variables on firm value is also controlled.

\section{Granger Causality}

Here the causality test, introduced by Granger (1969), is applied in order to evaluate the causal relationship between blockholder ownership and firm value and to test the robustness of the result achieved from GMM to investigate further whether there are any causal relationships between NBH/MBH and firm value, and also to explore whether changes in the cause variable leads to changes in the effect variable. First we applied the stationary test to avoid any spurious causality results. In this case, the study would estimate misleading inferences about the measured parameters and the degree of their connotations.

According to Hamilton (1994) and Thomsen et al. (2006), the causality test between ownership concentration and firm value considers firm value as a forward looking variable. It means that investors might predict the firm value changes and therefore firm value can cause changes in block sizes that shareholder own. Hence, considering firm value as a forward looking variable is essential in this study because an AIM company is allowed to postpone the disclosure of information that relates to forthcoming developments or matters in the process of negotiation. 
This implies, if large blockholders have inside information, they may increase (decrease) their ownership because they know that the firm value is likely to increase (decrease) in the next period. Thomsen et al. (2006) solve this problem by considering the changes in firm value before changes in shareholders' block sizes.

Here, in order to consider the firm specific effect, the Granger tests and panel data analysis should be combined so as to be able to overcome one of the main disadvantages of Granger causality, which is requiring time series information. To apply a standard Granger causality test, first a simple linear regression is considered to determine the cause, effect and the type of relationship. Equations 5 and 6 illustrate the causality relationship between non-managerial shareholders and firm value.

$$
\begin{aligned}
& \mathrm{FV}_{\mathrm{it}}=\mathrm{C}_{1}+\alpha_{1} \mathrm{NBH}_{\mathrm{t}-1}+\alpha_{2} \mathrm{FV}_{\mathrm{t}-1}+\mu_{1 \mathrm{t}} \\
& \mathrm{NBH}_{\mathrm{it}}=\mathrm{C}_{2}+\alpha_{3} \mathrm{NBH}_{\mathrm{t}-1}+\alpha_{4} \mathrm{FV}_{\mathrm{t}-1}+\mu_{1 \mathrm{t}}
\end{aligned}
$$

Moreover, equations (7) and (8) below show the causality relationship between managerial blockholders and firm value.

$$
\begin{aligned}
& \mathrm{FV}_{\text {it }}=\mathrm{C}_{1}^{\prime}+\gamma_{1} \mathrm{MBH}_{\mathrm{t}-1}+\gamma_{2} \mathrm{FV}_{\mathrm{t}-1}+\mu_{1 \mathrm{t}} \\
& \mathrm{MBH}_{\mathrm{it}}=\mathrm{C}_{2}^{\prime}+\gamma_{3} \mathrm{MBH}_{\mathrm{t}-1}+\gamma_{4} \mathrm{FV}_{\mathrm{t}-1}+\mu_{1 \mathrm{t}}
\end{aligned}
$$

Where:

- $\quad \alpha_{1}\left(\gamma_{1}\right) \neq 0$ and $\alpha_{2}\left(\gamma_{2}\right)=0$ indicates that there is unidirectional Granger causality from non-managerial (managerial) blockholder to firm value. Therefore the blockholder would be the predictor of firm value.

- $\quad \alpha_{1}\left(\gamma_{1}\right)=0$ and $\alpha_{2}\left(\gamma_{2}\right) \neq 0$, indicates that the unidirectional Granger causality is from firm value to non-managerial (managerial) blockholder; thus it can be concluded that firm value is a blockholder predictor.

- $\alpha_{1}\left(\gamma_{1}\right) \neq 0$ and $\alpha_{2}\left(\gamma_{2}\right) \neq 0$ specifies that there is bi-directional Granger causality between firm value and non-managerial (managerial) blockholders; therefore both firm value and non-managerial (managerial) blockholders have a mutual impact.

However, blockholders can impact firm value directly and indirectly (Thomsen et al., 2006). The direct impact can be estimated by the change of blockholders following the change of firm value, whereas the indirect impact should consider the change of blockholder before the change in firm value, this implies blockholders might have inside information about the firm; which this may lead them to sell or buy shares before a change in firm value. While this is illegal in 
the AIM, the possibility cannot be excluded that blockholders sell or buy shares because of their inside information about firm value that might fall or rise in the next period. Also to measure the firm value Tobin's Q which it is a known concept that has been used in finance researches for the value of the firm in various studies (Morck et al., 1988; Holderness and Sheehan, 1988; Claessens et al., 2002; Cronqvist and Nilsson, 2003; Lins, 2003; Anderson and Reeb, 2004; Fahlenbrach, 2004; Black, 2005). In this study the firm size ${ }^{7}$, leverage is used to consider structural differences that companies use in terms of their long- and short-term financing tools in different countries. Furthermore, intangible assets used as another control variable, because intangible assets proxy for future growth opportunities.

\section{Findings and Results}

This study creates an unbalanced panel data which in total 805 companies were extracted from DataStream as companies listed in the AIM as at $31^{\text {st }}$ December 2013. Here we consider blockholders as shareholders who own at least five per cent of the total firm shares. Therefore, companies whose largest shareholders own fewer than five per cent of total shares were dropped from the sample. Also, as the study uses lags to test the association between the variables, following Miguel et al. (2006), only those firms which have information available for at least six consecutive years (2008-2013) remained in the sample. ${ }^{8}$ Moreover, following Lins (2003) and Miguel et al. (2006), financial companies are removed from the sample. Hence the final sample includes 443 companies. Companies' financial information was extracted from DataStream and the information about block sizes was extracted from Thomson One Banker. Table 1 illustrates that the number of non-managerial blockholders is higher than the number of managerial blockholders. Generally, the sample includes 318 non-managerial blockholders and 125 managerial blockholders. It also illustrates that most of the non-managerial and managerial blockholders have up to 30 per cent of total shares. Next, Table 2 shows the descriptive statistics of data used here which it justifies that the means of the main variables, which are ownership concentration and the firm value, are not significantly different between the two groups, NBH and MBH. Therefore, it can be concluded that the ownership is concentrated at the same level in both managerial and non-managerial groups of blockholders in the AIM. However, among control variables, it indicates that the NBH companies are larger in terms of size. Clearly then, the companies with external blockholders are larger than companies with insider blockholders.

\footnotetext{
${ }^{7}$ measured by a log of assets

${ }^{8}$ As Miguel et al. (2006) explain, this condition is necessary in order to have enough periods when testing for the second-order serial correlation in the GMM.
} 
Table 1- Non-managerial and managerial block sizes

\begin{tabular}{l|l|l|l}
\hline Block size & Non-managerial & Managerial & Total \\
\hline $5 \%$ - under $10 \%$ & 43 & 22 & 65 \\
$10 \%$ - under $15 \%$ & 76 & 26 & 102 \\
$15 \%$ - under $20 \%$ & 64 & 31 & 95 \\
$20 \%$ - under $25 \%$ & 45 & 14 & 59 \\
$25 \%$ - under $30 \%$ & 45 & 12 & 57 \\
$30 \%$ - under $35 \%$ & 9 & 5 & 14 \\
$35 \%$ - under $40 \%$ & 10 & 3 & 13 \\
$40 \%$ - under $45 \%$ & 9 & 2 & 11 \\
$45 \%$ - under $50 \%$ & 6 & 2 & 8 \\
Over $50 \%$ & 11 & 8 & 19 \\
\hline Total & 318 & 125 & 443 \\
\hline
\end{tabular}

Note: The sample includes 443 companies whose largest blockholders have at least $5 \%$ of total shares. The sample divided into two subsamples of 318 non-managerial blockholders and 125 managerial blockholders. Data about the blocksizes are extracted from Thomson One Banker.

Table 2- Descriptive Statistics of firm value (Tobin's Q) and ownership concentration and other control variables for both non-managerial blockholders and managerial blockholders

\begin{tabular}{c|c|cccccc}
\hline Variable & & $\begin{array}{c}\text { No } \\
\text { observations }\end{array}$ & Mean & $\begin{array}{c}\text { Mean } \\
\text { difference }\end{array}$ & StDev & Min & Max \\
\hline \multirow{5}{*}{ Tobin's Q } & All & 2871 & 0.338 & & 0.550 & 0.007 & 1.068 \\
& NBH & 1680 & 0.257 & \multirow{2}{*}{0.088} & 0.556 & 0.007 & 1.572 \\
& MBH & 746 & 0.366 & & 0.531 & 0.095 & 1.068 \\
\cline { 2 - 8 } Ownership & All & 4968 & 20.663 & & 12.315 & 5.000 & 69.23 \\
Concentration & NBH & 3410 & 20.489 & \multirow{2}{*}{0.061} & 11.941 & 5.000 & 61.52 \\
& MBH & 1768 & 21.137 & & 13.362 & 5.010 & 69.23 \\
\cline { 2 - 8 } Second largest & All & 4385 & 14.523 & \multirow{2}{*}{0.032} & 5.122 & 5.000 & 44.12 \\
Blockholder & NBH & 2923 & 14.103 & & 5.003 & 33.84 \\
& MBH & 1461 & 14.957 & & 5.025 & 5.000 & 44.12 \\
\cline { 2 - 8 } Firm size & All & 4350 & 3279 & & 1.621 & 0.000 & 29462 \\
& NBH & 2401 & 3054 & \multirow{2}{*}{$0.006^{* * * *}$} & 1.802 & 0.000 & 29462 \\
& MBH & 1134 & 3391 & & 0.566 & 0.000 & 22176 \\
\cline { 2 - 8 } Intangible assets & All & 4736 & 0.193 & & 0.000 & 2700 \\
& NBH & 2654 & 0.259 & \multirow{2}{*}{0.090} & 0.929 & 0.000 & 2700 \\
& MBH & 1215 & 0.162 & & 0.475 & 0.000 & 5981 \\
\cline { 2 - 8 } & All & 3173 & 0.585 & & 0.451 & 0.019 & 1.583 \\
Leverage & NBH & 1806 & 0.143 & \multirow{2}{*}{0.618} & 0.498 & 0.019 & 1.523 \\
& MBH & 839 & 0.518 & & 0.445 & 0.011 & 1.583 \\
\hline
\end{tabular}

Note: All blockholders are inclusive of NBH and MBH; Number of observations (N) is the number of years observations of available data. Mean-difference is the difference between the mean of the NBH with the mean of MBH. 
The Column 1 of Table 3 represents the results of GMM estimations that have been applied in order to evaluate the impact of NBH on Tobin's Q. The statistical significance and the opposite signs of the coefficients of NBH and NBH2 confirm that the relationship between NBH and firm value is quadratic with point of maxima as predicted by the hypothesis I. The value of $\mathrm{NBH}$ at this breakpoint can be obtained as follow:

$$
\mathrm{NBH}=-\beta_{1} / 2 \beta_{2}=32 \%
$$

This implies in the firms which have non-managerial blockholders, the firm value increases as ownership concentration rises from five per cent to 32 per cent; however, when the block size of non-managerial blockholders exceeds 32 per cent, it has an inverse relationship with firm value. This result shows that the non-managerial blockholders who own between five per cent and 32 per cent of total shares monitor the company's managers more efficiently, while the non-managerial blockholders who own more than 32 per cent of total shares expropriate minority shareholders, as shown in Figure 1.

The results in Table 3 show that in the AIM of the London Stock Exchange, non-managerial blockholders affect the firm value significantly. This might originate from the AIM rules for companies that do not require them to adhere to a particular set of corporate governance rules, and let the insiders delay information announcement. Therefore, non-managerial blockholders owning between five per cent and 32 per cent of total shares might bear the whole additional cost of increased monitoring, while earning the profit arising from the improved monitoring on a pro rata basis (the free rider problem) in order to protect themselves from being expropriated by managers in the weak corporate governance environment. Furthermore, the results illustrate that non-managerial blockholders owning more than 32 per cent of total shares reduce the firm value; this also can be explained by the AIM rules that do not emphasise the independency of the company, the corporate governance of the main market of the London Stock Exchange does not allow companies to have blockholders with more than 30 per cent of total shares. However, as the corporate governance of the AIM does not emphasise the independency of the company and allows the firm to have large blockholders and delay the announcements of information, the large blockholders are able to expropriate small shareholders and negatively affect the firm value. 


\begin{tabular}{|c|c|c|}
\hline & (1) & (2) \\
\hline Constant & $\begin{array}{l}0.4054 \\
(1.33)\end{array}$ & $\begin{array}{c}-0.292 \\
(-0.341)\end{array}$ \\
\hline NBH & $\begin{array}{c}0.0132^{* *} \\
(2.48)\end{array}$ & \\
\hline $\mathrm{NBH}^{2}$ & $\begin{array}{c}-0.0008^{* *} \\
(-2.41)\end{array}$ & \\
\hline $\mathrm{MBH}$ & & $\begin{array}{c}0.422^{* * *} \\
(3.17)\end{array}$ \\
\hline $\mathrm{MBH}^{2}$ & & $\begin{array}{c}-1.582^{* * *} \\
(-2.61)\end{array}$ \\
\hline $\mathrm{MBH}^{3}$ & & $\begin{array}{l}1.231^{* *} \\
(2.44)\end{array}$ \\
\hline $\begin{array}{c}\text { Second Largest } \\
\text { BH }\end{array}$ & $\begin{array}{l}0.000 \\
(1.32)\end{array}$ & $\begin{array}{l}0.001 \\
(1.94)\end{array}$ \\
\hline Tobin's QL1 & $\begin{array}{c}0.1395^{* *} \\
(1.89)\end{array}$ & $\begin{array}{c}1.103^{* * *} \\
(2.89)\end{array}$ \\
\hline Firm size & $\begin{array}{c}-0.1533^{* * *} \\
(-2.93)\end{array}$ & $\begin{array}{l}-0.0458 \\
(-2.39)\end{array}$ \\
\hline Intangibles & $\begin{array}{c}0.0509^{* * *} \\
(5.44)\end{array}$ & $\begin{array}{l}0.000 \\
(0.37)\end{array}$ \\
\hline Leverage & $\begin{array}{c}0.0000^{*} \\
(2.91)\end{array}$ & $\begin{array}{c}0.021^{* * *} \\
(2.98)\end{array}$ \\
\hline $\mathrm{Z}$ & 1875.64 & 8292.31 \\
\hline $\operatorname{AR}(1)$ & $-0.923^{* *}$ & $-0.007^{* *}$ \\
\hline $\operatorname{AR}(2)$ & -0.425 & -0.018 \\
\hline Sargan & 20.56 & 18.24 \\
\hline
\end{tabular}

Note: $\mathrm{FV}_{\mathrm{it}}=\beta_{0}+\beta_{1} \mathrm{NBH}_{\mathrm{it}}+\beta_{2} N B H_{i t}^{2}+\beta_{\mathrm{it}} \mathrm{FV}_{\mathrm{t}-1}+\beta_{\mathrm{it}} \mathrm{C}_{\mathrm{it}}+\mathrm{d}_{\mathrm{t}}+\eta_{\mathrm{i}}+v_{\mathrm{it}} ; \mathrm{FV}_{\mathrm{it}}=\omega_{0}+\omega_{1} \mathrm{MBH}_{\mathrm{it}}+\omega_{2} M B H_{i t}^{2}+$ $\omega_{3} M B H_{i t}^{3}+\omega_{\mathrm{it}} \mathrm{FV}_{\mathrm{t}-1}+\omega_{\mathrm{it}} \mathrm{C}_{\mathrm{it}}+\mathrm{d}_{\mathrm{t}}+\eta_{\mathrm{i}}+v_{\mathrm{it}} . \mathrm{z}$ is a Wald test of the joint significance of the reported coefficients, asymptotically distributed under the null of no relationship

Moreover, the result here shows that firm size has a significant negative correlation with firm value. The negative relationship between firm value and firm size can be supported by the argument mentioned by Maury and Pajuste (2005), Miguel et al. (2006) and Hadani et al. (2011). They stated that larger firms are likely to have a higher level of information asymmetry and hence a more severe agency problem that results in reduced firm value. In addition, it can be seen that leverage and intangible fixed assets are positively correlated. Maury and Pajuste (2005) identified that leverage can positively affect the firm value by playing a disciplinary role and restraining the free cash flow at hand, thus decreasing profit diversion. In support to Miguel et al. (2006), the direct relationship between firm value and intangible fixed assets confirms the prediction that this variable proxies for future growth opportunities. ${ }^{9}$

\footnotetext{
${ }^{9}$ Maury and Pajuste (2005) explain that a higher proportion of intangible assets such as human capital can result in generating higher cash flows.
} 
We identified that the weak corporate governance of the AIM encourages blockholders who have block sizes of between five per cent and 32 per cent to monitor managers in order to protect themselves, and thus increase the firm value. However, the AIM corporate governance system allows large blockholders to expropriate small shareholders for their own benefit, hence decreasing the firm value. Thus the findings of this study support Shleifer and Vishny (1997), who argue that in companies with low ownership concentration, the agency problem originates from the conflict between managers and outsider dispersed shareholders, while in companies with high ownership concentration, the agency problem comes from the conflict between large and small shareholders.

Therefore the column 1 of table 3 supports the hypothesis I, whereas the firm value first rises and, after a breakpoint, declines as block size increases. The Column 2 in Table 3 shows the results of GMM estimations that have been applied in order to evaluate the impact of $\mathrm{MBH}$ on Tobin's Q. It indicates that the statistical significance and the signs of the coefficients of MBH, $\mathrm{MBH}^{2}$, and $\mathrm{MBH}^{3}$ confirm that the relationship between $\mathrm{MBH}$ and firm value is cubic. Also, the coefficient signs of $\mathrm{MBH}_{2}$ and $\mathrm{MBH}_{3}$ prove that the first breakpoint of the cubic function is a point of maxima and the second stationary point is a point of minima, as shown in Figure 2. The stationary point of cubic function of equation 2 can be computed from the following equation:

$$
\mathrm{MBH}_{1,2}=\frac{-2 \omega_{2} \pm \sqrt{4 \omega_{2}^{2}-12 \omega_{1} \omega_{3}}}{6 \omega_{3}}=31 \% \text { and } 54 \%
$$

Consequently, the result confirms the existence of both convergence of interest and the entrenchment effect on the relationship between $\mathrm{MBH}$ and firm value. This implies that for MBH values between five per cent and 31 per cent, any increase in block size will result in an increase in the firm value, because of greater incentives for $\mathrm{MBH}$ to maximize value as their block size increases. However, when $\mathrm{MBH}$ ranges from 31 per cent to 54 per cent, firm value decreases by any increase in MBH. This result explains that rises in MBH between 31 per cent and 54 per cent cause managerial blockholders to be less concerned about the benefit to the rest of the shareholders, and their larger block sizes and the weak corporate governance of the AIM enable them to entrench themselves. Finally, for the very large $\mathrm{MBH}$, above 54 per cent, convergence of interest again controls the relationship. Therefore the column 2 of the table 3 confirms the hypothesis II, whereas the firm value first increases, then decreases, and finally continues to increase as managerial block size rises, is supported. Moreover the negative sign 
of second largest blockholder is also illustrating that distribution of power in the company result to less expropriation by the largest shareholder.

Therefore, in line with the result of Maury and Pajuste (2005) the second largest block size has positive impact on the firm value. As illustrated from GMM estimation, both NBH and MBH have a significant impact on the firm value. However, as mentioned by Thomsen et al. (2006), the causation could, in some circumstances, run in the opposite direction. Hence here we evaluate the reverse causality between NBH/MBH and Tobin's $Q$ to find out whether or not firm value has an impact on the $\mathrm{NBH}$ and $\mathrm{MBH}$. To avoid the spurious causality results first we applied the panel contains unit root and Table 4 illustrates the results of the unit root tests on NBH/MBH and Tobin's Q, firm size, leverage and intangibles. This result indicates that all main and control variables are significant at $1 \%$ level of significance; therefore the null hypothesis is strongly rejected and all variables are stationary.

Table 4- The result of Unit root test on NBH/MBH and Tobin's Q, firm size, leverage and intangibles

\begin{tabular}{|c|c|c|c|c|c|}
\hline Variable & Blockholder type & Statistic & Probability & Statistic & Probability \\
\hline \multicolumn{2}{|c|}{ Panel A Main Variables } & \multicolumn{2}{|c|}{ Levin-Lin-Chu } & \multicolumn{2}{|c|}{ Harris-Tzavalis } \\
\hline \multirow{2}{*}{ Tobin's Q } & NBH & -6.423 & 0.000 & 0.495 & 0.000 \\
\hline & MBH & -3.832 & 0.000 & 0.530 & 0.000 \\
\hline \multirow{2}{*}{ Block size } & NBH & -4.951 & 0.000 & 0.000 & 0.000 \\
\hline & MBH & -4.101 & 0.000 & 0.000 & 0.000 \\
\hline \multicolumn{6}{|c|}{ Panel B Control Variables } \\
\hline \multirow{2}{*}{$\begin{array}{l}\text { Second Largest } \\
\text { BH }\end{array}$} & NBH & -3.001 & 0.000 & 0.000 & 0.000 \\
\hline & MBH & -4.009 & 0.000 & 0.000 & 0.000 \\
\hline \multirow{2}{*}{ Firm size } & NBH & -6.941 & 0.000 & 0.698 & 0.000 \\
\hline & MBH & -12.807 & 0.000 & 0.705 & 0.000 \\
\hline \multirow{2}{*}{ Leverage } & NBH & -5.017 & 0.000 & 0.734 & 0.000 \\
\hline & MBH & -4.010 & 0.000 & 0.447 & 0.000 \\
\hline \multirow{2}{*}{ Intangibles } & NBH & -10.089 & 0.000 & 0.613 & 0.000 \\
\hline & $\mathrm{MBH}$ & -4.004 & 0.000 & 0.689 & 0.000 \\
\hline
\end{tabular}

Note: The null and alternative hypotheses are: Ho: Panels contain unit roots.

Next the causality between blockholders and firm value are tested and the result from Table 5 reports the results of the causality test on NBH and Tobin's Q. Model I of both the OLS and 
fixed effect panel data presented in Table 3.5 shows the result of the causality test by considering only the changes of NBH and Tobin's Q, while Model II illustrates the outcome of the same tests by considering the control variables as well as the main variables. Also both Models I and II report an insignificant impact of Tobin's Q changes on the NBH, and also the second column of Model I and Model II present the impact of NBH on Tobin's Q. As expected and in line with the GMM result, both OLS and fixed effect panel data confirm that NBH changes have a strong significant impact on Tobin’s Q.

Furthermore, evaluating control variables illustrate that the signs of firm size, leverage and intangible fixed assets coefficients are the same as those shown by GMM when Tobin's Q is the dependent variable. However, when NBH is the dependent variable, the coefficient sign of the leverage variable is negative, but it is not significant. In addition, the negative relationship between NBH and firm size explains that larger companies have less concentrated ownership. Finally, it can be seen that intangible fixed assets have no significant impact on the NBH.

Table 6 shows the estimations for the group of NBH with less than $32 \%$ of total shares. The results shown in both models illustrate that Tobin's Q has no significant impact on the NBH, while testing the other side of causality shows that NBH has a significant impact on Tobin's Q. This result confirms that non-managerial blockholders with small and medium block sizes improve firm value by accepting the costs of monitoring managers. ${ }^{10}$

Furthermore, Table 7 reports the results of estimating Granger causality between Tobin's Q and the second group of NBH with block sizes larger than $32 \%$. The results shown in both models prove that Tobin's Q has no significant impact on the NBH, while NBH has significant impact on Tobin's Q. The negative relationship reported between Tobin's Q and NBH clarifies that for any increase in managerial block sizes larger than 32 per cent, the firm value decreases, which confirms the result generated by applying GMM test.

Generally, the results obtained from Granger causality tests confirm the results from quadratic model by GMM estimation, showing that non-managerial blockholders of the AIM who own more than five per cent and less than 32 per cent of total shares improve the firm value because of their incentive to monitor managers. On the other hand, non-managerial blockholders having more than 32 per cent of total shares expropriate other shareholders by taking advantage of

\footnotetext{
${ }^{10}$ This finding is in line with the monitoring hypothesis mentioned by Gedajlovic and Shapiro (1998) and Miguel et al. (2006).
} 
their private information. It can be seen that the quadratic relationship between NBH and firm value is revealed with and without consideration of dynamic endogeneity; however, the level of significance is different in GMM and fixed effect panel data, which highlights the impact of considering dynamic endogeneity.

Previously the GMM estimation show that managerial blockholders have a significant impact on the firm value. Furthermore we applied, Granger causality tests to investigate whether firm value has a significant impact on managerial blockholders. Table 8 reports the result of an inverse relationship between $\mathrm{MBH}$ and Tobin's $\mathrm{Q}$ and shows that $\mathrm{MBH}$ has a significant impact on Tobin's Q, while Tobin's Q has no significant impact on the MBH.

Generally, based on the results achieved from analysing the relationship between NBH/MBH and Tobin's Q, we justified that in the AIM, blockholders have significant impact on the firm value, while firm value does not affect blockholders significantly. As mentioned by Miguel et al. (2006), the negative association between firm value and size explains that it is more difficult for insiders to own a significant fraction of a larger firm. Furthermore, the positive coefficient on debt confirms that debt and insider ownership can substitute one another to mitigate information and agency conflicts (Lins, 2003; Miguel et al., 2006). 


\section{Table 5- The result table of Granger causality test on Tobin's Q and NBH}

Note: This table reports the result of reverse causality between NBH and Tobin's Q by using the following regressions: $\mathrm{FV}_{\mathrm{it}}=\mathrm{C}_{1}+\alpha_{1} \mathrm{NBH}_{\mathrm{t}-1}+$ $\alpha_{2} \mathrm{FV}_{\mathrm{t}-1}+\mu_{1 \mathrm{t}}$; and $\mathrm{NBH}_{\mathrm{it}}=\mathrm{C}_{2}+\alpha_{3} \mathrm{NBH}_{\mathrm{t}-1}+\alpha_{4} \mathrm{FV}_{\mathrm{t}-1}+\mu_{1}$. The result obtained from OLS and fixed effect panel data estimations. The explanatory and control variables are defined in Table 4.A.1. Number $(\mathrm{N})$ of observations is the number of observations of available data. Reported in parentheses t-value is heteroskedasticity consistent (White, 1980) and adjusted for clustering at stock level. ‘***' indicates significance at $1 \%$, ‘**' indicates significance at $5 \%$.

\begin{tabular}{|c|c|c|c|c|c|c|c|c|}
\hline & \multicolumn{4}{|l|}{ OLS } & \multicolumn{4}{|c|}{ Fixed effect } \\
\hline & Model I & & Model II & & Model I & & Model II & \\
\hline & NBH & Tobin’s Q & $\mathrm{NBH}$ & Tobin’s Q & NBH & Tobin’s Q & NBH & Tobin’s Q \\
\hline Intercept & $\begin{array}{l}0.11 \\
(0.81)\end{array}$ & $\begin{array}{l}-0.036 \\
(-1.69)\end{array}$ & $\begin{array}{l}0.414 \\
(1.15)\end{array}$ & $\begin{array}{l}0.281^{* * *} \\
(7.86)\end{array}$ & $\begin{array}{l}22.58^{* * *} \\
(37.89)\end{array}$ & $\begin{array}{l}-0.705^{* * *} \\
(-5.40)\end{array}$ & $\begin{array}{l}22.09^{* * *} \\
(23.07)\end{array}$ & $\begin{array}{l}-0.090 \\
(-0.89)\end{array}$ \\
\hline Tobin’s Q-L1 & $\begin{array}{l}0.004 \\
(0.04)\end{array}$ & $\begin{array}{l}0.844^{* * *} \\
(43.95)\end{array}$ & $\begin{array}{l}0.010 \\
(0.82)\end{array}$ & $\begin{array}{l}0.532^{* * *} \\
(30.05)\end{array}$ & $\begin{array}{l}0.202 \\
(1.82)\end{array}$ & $\begin{array}{l}0.629^{* * *} \\
(25.16)\end{array}$ & $\begin{array}{l}0.192 \\
(1.18)\end{array}$ & $\begin{array}{l}0.298^{* * *} \\
(11.96)\end{array}$ \\
\hline NBH-L1 & $\begin{array}{l}0.992^{* * *} \\
(173.80)\end{array}$ & $\begin{array}{l}0.001 \\
(1.88)\end{array}$ & $\begin{array}{l}0.877^{* * *} \\
(39.00)\end{array}$ & $\begin{array}{l}0.003 \\
(1.67)\end{array}$ & $\begin{array}{l}0.127^{* * *} \\
(4.31)\end{array}$ & $\begin{array}{l}0.032^{* * *} \\
(5.02)\end{array}$ & $\begin{array}{l}0.259^{* * *} \\
(6.98)\end{array}$ & $\begin{array}{l}0.050^{* * *} \\
(4.62)\end{array}$ \\
\hline Second Largest BH & & & $\begin{array}{l}1.121 \\
(0.55)\end{array}$ & $\begin{array}{l}1.108 \\
(1.80)\end{array}$ & & & $\begin{array}{l}0.933 \\
(0.83)\end{array}$ & $\begin{array}{l}1.22 \\
(1.75)\end{array}$ \\
\hline Firm size & & & $\begin{array}{l}-0.021 \\
(-0.28)\end{array}$ & $\begin{array}{l}-0.105^{* * *} \\
(-12.84)\end{array}$ & & & $\begin{array}{l}-0.021 \\
(-0.19)\end{array}$ & $\begin{array}{l}-0.204^{* * *} \\
(-16.91)\end{array}$ \\
\hline Debt ratio & & & $\begin{array}{l}-0.001 \\
(-0.51)\end{array}$ & $\begin{array}{l}0.000 \\
(0.82)\end{array}$ & & & $\begin{array}{l}-0.001 \\
(-0.92)\end{array}$ & $\begin{array}{l}0.000 \\
(0.69)\end{array}$ \\
\hline Intangibles & & & $\begin{array}{l}0.000 \\
(0.68)\end{array}$ & $\begin{array}{l}0.000 \\
(0.09)\end{array}$ & & & $\begin{array}{l}0.079 \\
(0.81)\end{array}$ & $\begin{array}{l}0.000^{* * * *} \\
(6.95)\end{array}$ \\
\hline $\mathrm{N}$ (observations) & 1345 & 1133 & 1195 & 1033 & 1345 & 1133 & 1195 & 1033 \\
\hline
\end{tabular}




\section{Table 6- The result table of Granger causality test on Tobin's Q and NBH less than $32 \%$}

Note: This table reports the result of reverse causality between $\mathrm{NBH}$ and Tobin's Q, when $\mathrm{NBH}$ is less than $32 \%$. Regressions are defined as $\mathrm{FV}_{\mathrm{it}}=\mathrm{C}_{1}+\alpha_{1} \mathrm{NBH}_{\mathrm{t}-1}+\alpha_{2} \mathrm{FV}_{\mathrm{t}-1}$ $+\mu_{1 \mathrm{t}}$; and $\mathrm{NBH}_{\mathrm{it}}=\mathrm{C}_{2}+\alpha_{3} \mathrm{NBH}_{\mathrm{t}-1}+\alpha_{4} \mathrm{FV}_{\mathrm{t}-1}+\mu_{1}$. The result obtained from running OLS and fixed effect panel data estimations. The explanatory and control variables are defined in Table 4.A.1. Number (N) of observations is the number of observations of available data. Reported in parentheses t-value is heteroskedasticity consistent (White, 1980 ) and adjusted for clustering at stock level. '***' indicates significance at $1 \%$, ' $* *$ ' indicates significance at $5 \%$.

\begin{tabular}{|c|c|c|c|c|c|c|c|c|}
\hline & \multicolumn{4}{|l|}{ OLS } & \multicolumn{4}{|c|}{ Fixed effect } \\
\hline & Model I & & Model II & & Model I & & Model II & \\
\hline & $\mathrm{NBH}$ & Tobin’s Q & $\mathrm{NBH}$ & Tobin’s Q & $\mathrm{NBH}$ & Tobin’s Q & $\mathrm{NBH}$ & Tobin's Q \\
\hline Intercept & $\begin{array}{l}0.307^{* * *} \\
(3.05)\end{array}$ & $\begin{array}{l}-0.921^{* * *} \\
(-4.99)\end{array}$ & $\begin{array}{l}0.548^{* *} \\
(2.44)\end{array}$ & $\begin{array}{l}0.503^{* * *} \\
(5.01)\end{array}$ & $\begin{array}{l}16.94^{* * *} \\
(49.09)\end{array}$ & $\begin{array}{l}-1.55^{* * *} \\
(-16.62)\end{array}$ & $\begin{array}{l}17.48^{* * *} \\
(39.87)\end{array}$ & $\begin{array}{l}-0.569^{* * *} \\
(-6.06)\end{array}$ \\
\hline Tobin’s Q-L1 & $\begin{array}{l}0.123 \\
(1.60)\end{array}$ & $\begin{array}{l}0.872^{* * *} \\
(58.54)\end{array}$ & $\begin{array}{l}0.280 \\
(1.12)\end{array}$ & $\begin{array}{l}0.749^{* * *} \\
(39.65)\end{array}$ & $\begin{array}{l}0.000 \\
(0.06)\end{array}$ & $\begin{array}{l}0.768^{* * *} \\
(44.68)\end{array}$ & $\begin{array}{l}1.92 \\
(0.36)\end{array}$ & $\begin{array}{l}0.478^{* * *} \\
(21.70)\end{array}$ \\
\hline NBH-L1 & $\begin{array}{l}0.974^{* * *} \\
(19.41)\end{array}$ & $\begin{array}{l}0.003^{* * *} \\
(4.39)\end{array}$ & $\begin{array}{l}0.782^{* * *} \\
(19.80)\end{array}$ & $\begin{array}{l}0.020^{* * *} \\
(4.30)\end{array}$ & $\begin{array}{l}0.022 \\
(1.15)\end{array}$ & $\begin{array}{l}0.085^{* * *} \\
(16.00)\end{array}$ & $\begin{array}{l}0.021 \\
(0.71)\end{array}$ & $\begin{array}{l}0.091^{* * *} \\
(10.09)\end{array}$ \\
\hline Second Largest BH & & & $\begin{array}{l}0.650 \\
(1.91)\end{array}$ & $\begin{array}{l}1.347^{* *} \\
(2.56)\end{array}$ & & & $\begin{array}{l}0.570 \\
(1.64)\end{array}$ & $\begin{array}{l}1.152^{* *} \\
(2.49)\end{array}$ \\
\hline Firm size & & & $\begin{array}{l}-0.019 \\
(-0.85)\end{array}$ & $\begin{array}{l}-0.101^{* * *} \\
(-8.56)\end{array}$ & & & $\begin{array}{l}-0.083^{* *} \\
(-2.58)\end{array}$ & $\begin{array}{l}-0.127^{* * *} \\
(-4.81)\end{array}$ \\
\hline Debt ratio & & & $\begin{array}{l}-0.000 \\
(-0.07)\end{array}$ & $\begin{array}{l}0.008^{* * *} \\
(2.97)\end{array}$ & & & $\begin{array}{l}0.000 \\
(1.12)\end{array}$ & $\begin{array}{l}0.005 \\
(2.18)\end{array}$ \\
\hline Intangibles & & & $\begin{array}{l}0.130 \\
(0.50)\end{array}$ & $\begin{array}{l}0.301^{* *} \\
(2.41)\end{array}$ & & & $\begin{array}{l}0.342 \\
(0.87)\end{array}$ & $\begin{array}{l}0.81 \\
(0.30)\end{array}$ \\
\hline & 1881 & 1634 & 1202 & 1135 & 2757 & 1634 & 2023 & 1135 \\
\hline $\mathrm{N}$ (observations) & 1989 & 1756 & 1212 & 1183 & 2952 & 1817 & 2004 & 1176 \\
\hline
\end{tabular}




\section{Table 7- The result of Granger causality test on Tobin's Q and NBH greater than $32 \%$}

Note: This table reports the result of reverse causality between $\mathrm{NBH}$ and Tobin's $\mathrm{Q}$, when $\mathrm{NBH}$ is greater than $32 \%$. Regressions are defined as $\mathrm{FV}_{\mathrm{it}}=\mathrm{C}_{1}+\alpha_{1} \mathrm{NBH}_{\mathrm{t}-1}+$ $\alpha_{2} \mathrm{FV}_{\mathrm{t}-1}+\mu_{1 \mathrm{t}}$; and $\mathrm{NBH}_{\mathrm{it}}=\mathrm{C}_{2}+\alpha_{3} \mathrm{NBH}_{\mathrm{t}-1}+\alpha_{4} \mathrm{FV}_{\mathrm{t}-1}+\mu_{1}$. The result obtained from OLS and fixed effect panel data estimations. The explanatory and control variables are defined in Table 4.A.1. Number $(\mathrm{N})$ of observations is the number of observations of available data. Reported in parentheses t-value is heteroskedasticity consistent (White, 1980 ) and adjusted for clustering at stock level. ' $* * *$ ’ indicates significance at $1 \%$, ' $* *$ ' indicates significance at $5 \%$.

\begin{tabular}{|c|c|c|c|c|c|c|c|c|}
\hline & \multicolumn{4}{|l|}{ OLS } & \multicolumn{4}{|c|}{ Fixed effect } \\
\hline & Model I & & Model II & & Model I & & Model II & \\
\hline & $\mathrm{NBH}$ & Tobin’s Q & $\mathrm{NBH}$ & Tobin’s Q & $\mathrm{NBH}$ & Tobin’s Q & $\mathrm{NBH}$ & Tobin's Q \\
\hline Intercept & $\begin{array}{l}9.173^{* * *} \\
(5.31)\end{array}$ & $\begin{array}{l}0.166 \\
(0.74)\end{array}$ & $\begin{array}{l}9.315 \\
(4.65)\end{array}$ & $\begin{array}{l}0.245^{* * *} \\
(6.35)\end{array}$ & $\begin{array}{l}53.292^{* * *} \\
(19.34)\end{array}$ & $\begin{array}{l}1.677^{* * *} \\
(5.07)\end{array}$ & $\begin{array}{l}45.401^{* * *} \\
(12.52)\end{array}$ & $\begin{array}{l}1.237^{* * *} \\
(4.98)\end{array}$ \\
\hline Tobin's Q-L1 & $\begin{array}{l}-0.000 \\
(-0.49)\end{array}$ & $\begin{array}{l}0.091^{* * *} \\
(6.62)\end{array}$ & $\begin{array}{l}-0.082 \\
(-1.61)\end{array}$ & $\begin{array}{l}0.681^{* * *} \\
(5.05)\end{array}$ & $\begin{array}{l}-0.002 \\
(-0.05)\end{array}$ & $\begin{array}{l}0.613^{* * *} \\
(9.15)\end{array}$ & $\begin{array}{l}-0.021 \\
(-0.28)\end{array}$ & $\begin{array}{l}0.189^{* * *} \\
(3.74)\end{array}$ \\
\hline NBH-L1 & $\begin{array}{l}0.807^{* * *} \\
(22.17)\end{array}$ & $\begin{array}{l}-0.011^{* * *} \\
(-2.51)\end{array}$ & $\begin{array}{l}0.869^{* * *} \\
(14.39)\end{array}$ & $\begin{array}{l}-0.000^{* *} \\
(2.61)\end{array}$ & $\begin{array}{l}0.102 \\
(1.80)\end{array}$ & $\begin{array}{l}-0.037^{* * *} \\
(-5.38)\end{array}$ & $\begin{array}{l}0.173^{* * *} \\
(2.64)\end{array}$ & $\begin{array}{l}-0.037^{* * *} \\
(-4.29)\end{array}$ \\
\hline Second Largest BH & & & $\begin{array}{l}1.370 \\
(1.52)\end{array}$ & $\begin{array}{l}-3.04 \\
(-1.78)\end{array}$ & & & $\begin{array}{l}0.971 \\
(1.76)\end{array}$ & $\begin{array}{l}-1.490 \\
(-1.23)\end{array}$ \\
\hline Firm size & & & $\begin{array}{l}-0.035 \\
(-0.79)\end{array}$ & $\begin{array}{l}-0.057^{* * *} \\
(-11.89)\end{array}$ & & & $\begin{array}{l}0.532^{* *} \\
(2.36)\end{array}$ & $\begin{array}{l}-0.216^{* * *} \\
(-7.85)\end{array}$ \\
\hline Debt ratio & & & $\begin{array}{l}-0.000 \\
(-0.07)\end{array}$ & $\begin{array}{l}0.025 \\
(1.23)\end{array}$ & & & $\begin{array}{l}-0.069 \\
(-0.74)\end{array}$ & $\begin{array}{l}0.020 \\
(0.97)\end{array}$ \\
\hline Intangibles & & & $\begin{array}{l}0.110 \\
(0.23)\end{array}$ & $\begin{array}{l}0.029^{* * *} \\
(2.93)\end{array}$ & & & $\begin{array}{l}0.000 \\
(0.45)\end{array}$ & $\begin{array}{l}0.000^{* *} \\
(2.37)\end{array}$ \\
\hline N (observations) & 244 & 163 & 168 & 127 & 331 & 150 & 325 & 203 \\
\hline
\end{tabular}


Table 8- The result table of Granger causality test on Tobin's Q and MBH

Note: This table reports the result of reverse causality between $\mathrm{NBH}$ and Tobin's Q by using the following regressions: $\mathrm{FV}_{\mathrm{it}}=\mathrm{C}_{1}+\alpha_{1} \mathrm{NBH}_{\mathrm{t}-1}+\alpha_{2} \mathrm{FV} \mathrm{V}_{\mathrm{t}-1}+\mu_{1 \mathrm{t}}$; and $\mathrm{NBH}_{\mathrm{it}}=\mathrm{C}_{2}$ $+\alpha_{3} \mathrm{NBH}_{\mathrm{t}-1}+\alpha_{4} \mathrm{FV}_{\mathrm{t}-1}+\mu_{1}$. The result obtained from OLS and fixed effect panel data estimations. The explanatory and control variables are defined in Table 4.A.1. Number (N) of observations is the number of observations of available data. Reported in parentheses t-value is heteroskedasticity consistent (White, 1980) and adjusted for clustering at stock level. ' $* * *$ ’ indicates significance at $1 \%$, ‘**' indicates significance at $5 \%$.

\begin{tabular}{|c|c|c|c|c|c|c|c|c|}
\hline & \multicolumn{4}{|l|}{ OLS } & \multicolumn{4}{|c|}{ Fixed effect } \\
\hline & Model I & & Model II & & & & Model I & \\
\hline & $\mathrm{MBH}$ & Tobin’s Q & $\mathrm{MBH}$ & Tobin’s Q & $\mathrm{MBH}$ & Tobin's Q & $\mathrm{MBH}$ & Tobin's Q \\
\hline Intercept & $\begin{array}{l}-0.098^{* * *} \\
(-2.99)\end{array}$ & $\begin{array}{l}0.038^{* *} \\
(2.25)\end{array}$ & $\begin{array}{l}-0.153 \\
(-2.05)\end{array}$ & $\begin{array}{l}0.061 \\
(1.06)\end{array}$ & $\begin{array}{l}53.021^{* * *} \\
(5.77)\end{array}$ & $\begin{array}{l}39.390^{* * *} \\
(4.36)\end{array}$ & $\begin{array}{l}107.329^{* * *} \\
(6.40)\end{array}$ & $\begin{array}{l}44.05^{* * *} \\
(3.89)\end{array}$ \\
\hline Tobin’s Q-L1 & $\begin{array}{l}-0.009 \\
(-0.85)\end{array}$ & $\begin{array}{l}1.019^{* * *} \\
(183.46)\end{array}$ & $\begin{array}{l}-0.12 \\
(-0.48)\end{array}$ & $\begin{array}{l}1.001^{* * *} \\
(182.98)\end{array}$ & $\begin{array}{l}0.000 \\
(0.10)\end{array}$ & $\begin{array}{l}0.725^{* * *} \\
(20.01)\end{array}$ & $\begin{array}{l}0.000 \\
(0.51)\end{array}$ & $\begin{array}{l}0.631^{* * *} \\
(8.23)\end{array}$ \\
\hline MBH-L1 & $\begin{array}{l}0.999^{* * *} \\
(3.56)\end{array}$ & $\begin{array}{l}0.000^{*} \\
(1.86)\end{array}$ & $\begin{array}{l}1.531^{* * *} \\
(4.01)\end{array}$ & $\begin{array}{l}0.000^{* *} \\
(2.37)\end{array}$ & $\begin{array}{l}0.911^{* * *} \\
(5.99)\end{array}$ & $\begin{array}{l}0.069^{* * *} \\
(4.36)\end{array}$ & $\begin{array}{l}0.982^{* * *} \\
(3.21)\end{array}$ & $\begin{array}{l}0.126^{* * *} \\
(3.04)\end{array}$ \\
\hline Second Largest BH & & & $\begin{array}{l}0.001 \\
(1.18)\end{array}$ & $\begin{array}{l}0.008 \\
(1.98)\end{array}$ & & & $\begin{array}{l}0.000 \\
(1.37)\end{array}$ & $\begin{array}{l}0.004 \\
(1.89)\end{array}$ \\
\hline Firm size & & & $\begin{array}{l}0.112 \\
(1.09)\end{array}$ & $\begin{array}{l}0.002 \\
(0.42)\end{array}$ & & & $\begin{array}{l}0.081^{* * *} \\
(3.87)\end{array}$ & $\begin{array}{l}-0.262^{* * *} \\
(-6.01)\end{array}$ \\
\hline Debt ratio & & & $\begin{array}{l}0.006 \\
0.17)\end{array}$ & $\begin{array}{l}0.000 \\
(0.11)\end{array}$ & & & $\begin{array}{l}0.002 \\
(0.24)\end{array}$ & $\begin{array}{l}0.000^{* * *} \\
(3.73)\end{array}$ \\
\hline Intangibles & & & $\begin{array}{l}0.017 \\
(1.04)\end{array}$ & $\begin{array}{l}0.000 \\
(0.08)\end{array}$ & & & $\begin{array}{l}0.142 \\
(1.56)\end{array}$ & $\begin{array}{l}0.106^{* * *} \\
(3.76)\end{array}$ \\
\hline N (observations) & 841 & 760 & 605 & 582 & 1089 & 627 & 731 & 528 \\
\hline
\end{tabular}




\section{Conclusion}

Different literature, such as Miguel et al. (2006) and Thomsen et al. (2006), mention that blockholders have no significant impact on the firm value in the UK because of the UK low ownership concentration and high investor protection. Considering the significance difference between the corporate governance of the main market of the London Stock Exchange and the AIM, this paper examines the relationship between the value of AIM companies and their ownership structures using panel data to eliminate unobservable firm heterogeneity. Moreover, as ownership concentration is an endogenous variable, the study should control for the endogeneity too. Also Henry (2010) mentions, ownership concentration endogeneity can be in the form of a dynamic sense and/or reverse causality. Thus, this study controls the dynamic sense of endogeneity by employing GMM, and the reverse causality by using the Granger causality test for panel data developed by Thomsen et al. (2006).

The findings of this study have important theoretical and managerial implications. In terms of Theoretical implications, this study finds evidence for both monitoring and expropriation hypotheses when studying the impact of external blockholders on the firm value and evidence for both convergence of interest and Entrenchment hypotheses when studying the impact of internal blockholders on the firms value. By following Lins (2003), Miguel et al. (2006), Edmans (2014) and Basu et al. (2016) we investigate the impact of managerial blockholders and also non-managerial blockholders on the firm value. Here we examined the impact of managerial and non-managerial blockholders separately by categorizing blockholders into two groups of non-managerial blockholders and managerial blockholders. Studying the association between non-managerial blockholders and the firm value reveals that both monitoring and expropriation hypotheses can explain the effect of non-managerial blockholders on the firm value. These two hypotheses are supported by defining a quadratic relationship between block sizes (that non-managerial blockholders hold) and the firm value. The empirical results extracted from GMM estimation here illustrated that non-managerial blockholders who own between five per cent and 32 per cent of total shares monitor managers and therefore are able to improve the firm value. However, non-managerial blockholders holding more than 32 per cent of total shares expropriate other shareholders and hence reduce the company's value.

Furthermore, evaluating the impact of managerial blockholders on the firm value supports both the convergence of interest and Entrenchment hypotheses by finding a cubic relationship. 
The empirical results of this study reveal that the interest of AIM managerial blockholders owning from five per cent to 31 per cent of total shares converges with the interest of other shareholders, and hence the firm value increases. These blockholders enrich themselves when they own 31-54 per cent of total shares and their interest converges with other shareholders' interests when they have large block sizes greater that 54 per cent. As previously mentioned, several studies find that in the UK, the ownership concentration is low and thus the impact of blockholders on the firm value is not significant (Thomsen et al., 2006; Miguel et al., 2006). This study contributes to the debate by providing evidence about the high ownership concentration in the AIM of the London Stock Exchange and showing that blockholder is one of the significant determinants of the value of firms listed in this sub-market of the UK. Moreover, testing the inverse causality between non-managerial/managerial blockholders and the firm value finds no effect of firm value on the ownership concentration. This result is consistent with the conjecture by Demsetz (1983). Although the results obtained by Granger causality confirm the curvilinear relationship defined between non-managerial blockholders and firm value, the significance of this impact varies when considering dynamic endogeneity by applying GMM. Therefore, it can be concluded that there is no reverse causality between blockholders and the firm value; however, it is important to consider the dynamic endogeneity.

In terms of managerial implications, this study seems to indicate that, blockholders do not always create value for firms listed in the AIM. Findings of this study should be of interest to managers of firms having internal or external blockholders. Managers of firms with external blockholders should alert that the firm value increases as ownership concentration rises from five per cent to 32 per cent as blockholder would accept the free rider problem and monitor the performance of managers thus the firm perfeormance and value would improve. However, when the block size of external blockholders exceeds 32 per cent, it would impact the firm value inversely. This result shows that the external blockholders who own more than 32 per cent of total shares expropriate minority shareholders by voice and exit. Moreover, managers should consider the fact that, even when blockholders are internal (part of management team), they still should pay close attention to those having blocks ranges from 31 per cent to 54 per cent as this group might expropriate other shareholders in their own benefit by taking advantage of their managerial authority. Finally, study findings also highlight the importance of managerial role in firms listed in the weak corporate governance markets such as AIM, as these firms normally have blockholders and because of high 
information asymmetry that the weak corporate governance create blockholders would find the opportunity to entrench themselves in cost of other shareholders.

The limitation of this study is the data availability and issues with missing observations. The main reason for data limitation and high volume of missing observation is that the companies in Alternative Investment Market are not required to submit their data, especially they are allowed to delay in publishing their internal information. This is generally because they are new and many of them are private companies with high level of information asymmetric. However this study minimize the range of scope of limitations throughout the research process. 


\section{References}

Admati, A.R. and Pfleiderer, P., 2009. The Wall Street Walk and shareholder activism: Exit as a form of voice. Review of Financial Studies, 22(7), pp.2645-2685.

Basu, N., Paeglis, I. and Rahnamaei, M., 2016. Multiple blockholders, power, and firm value. Journal of Banking \& Finance, 66, pp.66-78.

Bennedsen, M. and Nielsen, K.M., 2010. Incentive and entrenchment effects in European ownership. Journal of Banking \& Finance, 34(9), pp.2212-2229.

Bergström, C. and Rydqvist, K., 1990. Ownership of equity in dual-class firms. Journal of Banking \& Finance, 14(2-3), pp.255-269.

Bharath, S.T., Jayaraman, S. and Nagar, V., 2013. Exit as governance: An empirical analysis, The Journal of Finance, 68(6), pp. 2515-2547.

Bonaventura, M., Giudici, G. and Vismara, S., 2017. Valuation and performance of reallocated IPO shares. Journal of International Financial Markets, Institutions and Money.

Cheung, Y., Stouraitis, A. and Wong, A.W., 2005. Ownership concentration and executive compensation in closely held firms: Evidence from Hong Kong. Journal of Empirical Finance, 12(4), pp. 511-532.

Claessens, S., Djankov, S., Fan, J.P. and Lang, L.H., 2002. Disentangling the incentive and entrenchment effects of large shareholdings. The Journal of Finance, 57(6), pp. 2741-2771.

Demsetz, H. and Villalonga, B., 2001. Ownership structure and corporate performance. Journal of corporate finance, 7(3), pp. 209-233.

Edmans, A., 2014. Blockholders and corporate governance. Annual Review of Finance and Economics, 6(1), pp.23-50.

Edmans, A., 2009. Blockholder trading, market efficiency, and managerial myopia', The Journal of Finance, 64(6), pp. 2481-2513.

Edmans, A., Fang, V.W. and Zur, E., 2013. The effect of liquidity on governance. Review of Financial Studies, 26(6), pp. 1443. 
Edmans, A. and Manso, G., 2011. Governance through trading and intervention: A theory of multiple blockholders. Review of Financial Studies, 24(7), pp. 2395-2428.

Fama, E.F. and Jensen, M.C., 1983. Separation of ownership and control. The Journal of Law \& Economics, 26(2), pp. 301-325.

Florackis, C., Kostakis, A. and Ozkan, A., 2009. Managerial ownership and performance. Journal of Business Research, 62(12), 1350-1357

Gedajlovic, E.R. and Shapiro, D.M., 1998. Management and ownership effects: Evidence from five countries. Strategic Management Journal, 19(6), pp. 533-553.

Gompers, P., Ishii, J. and Metrick, A., 2003. Corporate governance and equity prices. The Quarterly Journal of Economics, 118(1), pp.107-156.

Grossman, S.J. and Hart, O.D., 1980. Takeover bids, the free-rider problem, and the theory of the corporation. The Bell Journal of Economics, 11(1), pp. 42-64.

Hadani, M., Goranova, M., and Khan R., 2011. Institutional investors, shareholder activism, and earnings management. Journal of Business Research, 64(12), pp. 1352-1360.

Han, K.C. and Suk, D.Y., 1998. The effect of ownership structure on firm performance: Additional evidence. Review of Financial Economics, 7(2), pp. 143-155.

Harris, M. and Raviv, A., 1988. Corporate governance: Voting rights and majority rules. Journal of Financial Economics, 20, pp. 203-235.

Hill, C.W. and Snell, S.A., 1989. Effects of ownership structure and control on corporate productivity. Academy of Management Journal, 32(1), pp. 25-46.

Jensen, M.C. and Meckling, W.H., 1976. Theory of the firm: Managerial behavior, agency costs and ownership structure. Journal of Financial Economics, 3(4), pp. 305-360.

Jiang, L., Kim, J.B. and Pang, L., 2011. Control-ownership wedge and investment sensitivity to stock price. Journal of Banking \& Finance, 35(11), pp.2856-2867.

Khan, R., Dharwadkar, R. and Brandes, P. 2005, Institutional ownership and CEO compensation: a longitudinal examination. Journal of Business Research, 58(8), pp. 1078-1088. 
Klapper, L.F. and Love, I., 2004. Corporate governance, investor protection, and performance in emerging markets. Journal of Corporate Finance, 10(5), pp. 703-728.

Lins, K.V., 2003. Equity ownership and firm value in emerging markets. Journal of Financial and Quantitative Analysis, 38(01), pp. 159-184.

Maury, B. and Pajuste, A., 2005. Multiple large shareholders and firm value. Journal of Banking \& Finance, 29(7), pp.1813-1834.

McConnell, J.J. and Servaes, H., 1990. Additional evidence on equity ownership and corporate value. Journal of Financial Economics, 27(2), pp. 595-612.

Morck, R., Nakamura, M. and Shivdasani, A., 2000. Banks, Ownership Structure, and Firm Value in Japan. The Journal of Business, 73(4), pp. 539-567.

Morck, R., Shleifer, A. and Vishny, R.W., 1988. Management ownership and market valuation: An empirical analysis. Journal of Financial Economics, 20, pp. 293-315.

Noe, T.H., 2002. Investor activism and financial market structure. Review of Financial Studies, 15(1), pp. 289-318.

Shleifer, A. and Vishny, R.W., 1997. A survey of corporate governance. The journal of finance, 52(2), pp. 737-783.

Shleifer, A. and Vishny, R.W., 1986. Large shareholders and corporate control', The Journal of Political Economy, pp. 461-488.

Stulz, R., 1988. Managerial control of voting rights: Financing policies and the market for corporate control. Journal of Financial Economics, 20, pp. 25-54.

Thomsen, S., Pedersen, T. and Kvist, H.K., 2006. Blockholder ownership: Effects on firm value in market and control based governance systems. Journal of Corporate finance, 12(2), pp. 246-269.

To, T.Y., Treepongkaruna, S. and Wu, E., 2017. Are all insiders on the inside? Evidence from the initiation of CDS trading and short selling in the financial sector. Journal of International Financial Markets, Institutions and Money.

Ursel, N.D. and Zhong, L., 2017. Why do Firms Pay High Underwriting Fees? SEO Withdrawal, Underwriter Certification and CEO Turnover. Journal of International Financial Markets, Institutions and Money. 
Velury, U. and Jenkins, S., 2006. Institutional ownership and the quality of earnings, Journal of Business Research, 59(9), pp. 1043-1051.

Yermack, D., 1996. Higher market valuation of companies with a small board of directors. Journal of Financial Economics, 40(2), pp. 185-211. 